\title{
A HistoriogRAPHY OF VEGETARIANISM IN ANTIQUITY
}

Alexandra Kovacs ${ }^{1}$

ABSTRACT: For the last few years, vegetarianism has been a social issue and at the centre of ethicoecological debates. Whereas the term exists since the $19^{\text {th }}$ century, many vegetarians affirm that the practise existed already in Antiquity and use great philosophical figures as examples. It is indeed indisputable that the abstinence from meat existed in Antiquity, however, this subject has been little exploited by historians. Considered for a long time as a marginal topic with a more philosophical than historical significance, the ancient vegetarianism aroused only tardily and recently the interest of researchers. This paper proposes to examine the historiography of this topic by showing how research on food, sacrifice and animals influenced research on ancient vegetarianism.

KEYWORDS: Historiography; Vegetarianism; Blood sacrifice; History of animals; History of food.

\section{Introduction}

Topic very fashionable this last decade, vegetarianism is currently a burning subject: there is not one week without a paper or a book being published either to proclaim the abstinence of meat or to condemn it. When each one has an argument to affirm his stance, history is regularly used by vegetarians to find support for their practice or even to affirm a diachronic cohesion (Larue, 2015). The risk is to see this topic monopolized by lobbies which can offer and impose a view of vegetarianism that is biased by presuppositions. My intention is not to settle this ethico-political question, nor to give a personal perspective, but to offer a historical analysis by proposing a reflection upon both the emergence of vegetarianism as a notion and as a research item especially for Antiquity, since the practice of a form of vegetarianism appears to go back to this period. Indeed, vegetarianism raises conjectural and synchronic questions: is the interest of scholars in such a subject explained by the social context and has the latter influenced the studies conducted these last years? Any historian, whether a specialist in Antiquity or not, is led to study topics that most often are an echo of contemporary concerns and he/she must examine this without risking to make anachronisms (Loraux, 1993, p. 24). As an individual in the world, a historian

\footnotetext{
${ }^{1}$ ISTA, University of Bourgogne Franche-Comté (France). E-mail: alexandra.kovacs@hotmail.fr
} 
becomes an observer and wonders about what surrounds himself/herself (Bloch, 2013, p. 65), ${ }^{2}$ as well as tries to understand the social mechanisms that set up in the light of history and to offer an objective scientific analysis.

First, I will go back over the notion of vegetarianism which is born in the late modern age and develops during the contemporary epoch. This clarification will help us understand how vegetarianism became a subject of research for the ancient periods. However, for a long time it remained a topic little investigated by historians for various reasons that will be introduced in a second part. Lastly, I will show that the multidisciplinary approach adopted in ancient history contributes to a historiographical renewal of the studies on ancient vegetarianism since a little under five years.

\section{A brief history of contemporary vegetarianism}

It is necessary to define what we call "vegetarianism". Literally, the term implies a food exclusively based on vegetables, cutting out meat products de facto. However, restricted to this definition, vegetarian becomes a synonym for herbivore. But, humans being naturally omnivorous, the adoption of a diet exclusively vegetable is a personal choice guided by convictions, by a representation of meat diet that one has and that urges one to reject it. Meat is a food item with which the eater (which must be understood in a generic and overall meaning) has a complex relationship, even paradoxical. Claude Fischler (2001, p. 118) sums it up clearly: meat "comporte à la fois une dimension fondamentalement psychologique et fondamentalement sociale. Elle met en jeu tous les ressorts de la sensibilité individuelle et, en même temps, dans toutes les sociétés, elle se situe au cœur même du lien social”. Therefore, abstaining from meat by adopting a vegetarian diet is an ideology in accordance with the eater's representation of animal flesh. 3 The arguments, varied, have in common that they answer to an idealization of a "healthy" life. Some are economical (the cost of animal production), others hygienic and sanitary (some people think that abstaining from meat reduces the risks of contracting some diseases), and others

\footnotetext{
2 "pour poser correctement les problèmes, pour en avoir même l'idée, une première condition a dû être remplie: observer, analyser le paysage d'aujourd'hui".

3 By animal flesh, I include fish as well as other meat.
} 
moral (rejection of animal killing) or ethico-ecological (responding to the growing needs of humans in meat destroys the environment and brings about the inevitable collapse of humanity) (Ossipow, 1997; Abrams, 2000, p. 1561-1563). These arguments reveal both the personal preoccupations of individuals and more generally the social preoccupations (Ouédraogo, 1994, p. 2-4). To understand this, we only have to observe the history of vegetarianism since the first appearance of the term in the $19^{\text {th }}$ century.

It stands to reason that the creation of the term "vegetarianism" implies that the practice existed beforehand. Indeed, it develops from the $18^{\text {th }}$ century on in England among ascetics who condemn the right to kill animals to feed, following the example of Thomas Tryon. Anabaptist, he refuses to consume animal flesh as well as to wear leather, inspired by the ideas of Pythagoras and those of Porphyry (Spencer, 1995, 206-209). As T. Tryon thinks that meat consumption is at the basis of the decline of society, Walter Charleston and John Wallis conduct scientific research on human anatomy in order to prove that human beings were not originally carnivorous. These works will be used as arguments for vegetarians. It is mainly the Methodist movement that will allow vegetarianism to spread. Close to George Cheyne, a physician, who affirms that the main diseases are caused by the changes of food habits due to the expansion of trade and exchanges, John Wesley (the father of Methodism) is inspired by his work to advocate a frugal diet and an ascetic way of life. Vegetarianism develops widely during the $19^{\text {th }}$ century, in England and in the United States within the dissident protestant movements, and then within philanthropic and hygienist movements (Ouédraogo, 1994, p. 16-29). The search for a healthy diet is to be understood with regards to the representation that individuals make of foodstuff at the time. Meat products in particular are blamed for the growth of instincts (excess, sex, alcohol). Also perceived as acidifiers during digestion and bringing about a fermentation and a putrefaction inside the digestive system, they are not advised, whereas vegetable foodstuffs, which are alkalizing, are recommended (Ossipow, 1989, p. 30-33). While many physicians are writing treatises in which the meatless diet is defended, the end of $19^{\text {th }}$ century sees vegetarian societies springing up in several countries: England (1847), United States (1851), Germany (1868), in Switzerland (1878), France (1880) and Belgium (1880). Vegetarianism is after all part of a general trend to look for a healthy life closer to nature (the 
development of naturism in the same period is a good testimony of that trend as well) in which food becomes the vehicle of an idealization of a way of life and a synonym of health. The renewed interest in the work of the physician Paul Carton in the 1930s, with the reprint of his book Les Trois Aliments Meurtriers, is revealing. 4 Fervent advocate of a healthy and vegetarian diet, his works incessantly link up health and wisdom by raising diet as asceticism (Ouédraogo, 1994, p. 113-117). 5

The reflection about the meat diet goes on during the second half of $20^{\text {th }}$ century and constructs itself with new arguments. At first, they are primarily economical. During 1960s, the expanding food industrialization is criticized by some dieticians who recommend a more agro-organic diet. Meat, particularly, gives rise to an acerbic condemnation of the economic consequences of this consumption by the Professor of medicine Jean Trémolières, whose arguments are taken up by these dieticians (Lepiller, 2013, p. 134). At the same time, emerges a discussion on animal ethic that can be defined as the moral responsibility of humans towards animals (Jeangène Vilmer, 2011, p. 79). ${ }^{6}$ It sees the light in England within the "Oxford Group" which is created in order to protest against industrial breeding. From then on appear, in the 1970s, anti-speciesists views with Richard Ryder, followed by Peter Singer who makes this movement visible to the public opinion with the publication of his book Animal Liberation in 1975. The latter opens the debates about the need of meat consumption, notably in western societies. These arguments still endure today and, in a context in which we worry about how to feed the ever growing humanity, the matter of meat food is at the heart of the discussions.

The aphorism of Jean-Anthelme Brillat-Savarin, "Tell me what you eat, I will tell you what you are", currently takes all its meaning. Whether one is carnivorous or vegetarian, the eater identifies oneself and affirms one's ideals by the food that one consumes. Eating meat becomes a practise that vegetarians point their finger at, because it is perceived by some as recklessness and selfishness. Conversely, vegetarians arouse the mistrust of many meat eaters who liken them to moralizers of what one must eat, having a nostalgic fervours of the

\footnotetext{
4 The three deadly foods are meat, sugar and alcohol.

5 See, for instance, Paul Carton's Bienheureux ceux qui souffrent.

6 "la responsabilité morale des hommes à l'égard des animaux".
} 
bohemian lifestyle and putting forward utopian arguments influenced by a fad effect (Lestel, 2011). A real division takes place between vegetarians and meat eaters, critically called by the firsts, the "carnists". Thus, many new labels describing the eater appear: whereas one who wants to eat meat in a reasonable quantity and is concerned with breeding and slaughtering conditions designates oneself as "flexitarian", the French abstinent of meat is no longer "végétarien" or "végétalien" but a "vegan" as to stand out from the vegetarianism of the previous generations and to affirm, beyond the way in which one feeds, a way of life turned towards ecological concerns.

Although the English term "vegan" has existed for several decades, in France its uses is a neologism which is wrongly used to designate both vegetarians and vegans. The level of abstinence from animal products is deleted by the need to affirm a commitment to ethico-ecological questions. 7 As for the one who refuses any label, he or she is relegated to the rank of the indifferent persons, as if it were absolutely necessary to attach oneself to a clan. In his book, Apologie du Carnivore, Dominique Lestel deplores (2011, p. 11) with a deliberately provocative tone that this "tendance à considérer qu'aimer les animaux et ne pas vouloir les manger sont deux attitudes qui vont de pair”. By establishing an argument in order to show the aporia of the ethical vegetarian discourse, D. Lestel constructs the discourse of an ethical carnivorous. Indeed, the arguments advanced by abstinents from meat are sometimes less concerned with the fate of animals than with the welfare of the consumers and their representation of nature, to which aesthetic criteria are often added (Burgat and Dantzer, 1997, p. 72-74).

The slaughter of some animals in particular rather than others is fought because we attach a particular affection to them: the death of seal puppies provokes more emotion in the public opinion than that of rats (Burgat \& Dantzer, 1997, p. 73). Such distinction depends largely on the representation we have of the animal and our attachment to some species. More generally, it depends on the definition we have of the animal and especially the elements used to distinguish it from humans. If we follow P. Singer, the only criterion to be taken

\footnotetext{
7 The stores take advantage of this renewed interest to develop products labelled as "vegan", mixed with some "organic" labels. Many consumers first look for this label, supposed to guarantee a healthy life, because here again it is the idea of a life in perfect harmony with nature that prevails.
} 
into account is not the intellectual qualities or physical differences, but rather its ability to feel pleasure or pain. Ethological researches since the 1970s change the perception of the animals and highlight their quality of being sensitive and reasoned. ${ }^{8}$ To this are added the actions of many non-profit organizations. The shocking videos of the French association L214 denouncing the conditions of slaughter of animals are meant to be informative and seek to raise public awareness about the conditions of animal killing in order to encourage individuals to no longer integrate meat into their meals. It is undoubtedly this awareness which explains that the relationship with meat has evolved in the last decades. As Annie Hubert (2007, p. 241) emphasizes, "La viande, la chair, un luxe pour nombre de leurs parents et grands-parents est devenue un objet de dégoût."

Defining vegetarianism since the term has appeared allows to wonder about the pertinence of its use for the previous periods. 9 Even if the word appears only at the end of the $19^{\text {th }}$ century, the notion is constructed and the practices developed in the contemporary epoch, this does not mean that forms of vegetarianism did not exist before. This is what scholars have seen, who, braving the suspicion of anachronism, have used the notion to study the reality of this phenomenon in earlier periods. This is particularly the case for Antiquity, which furthermore has often been used as an argument by vegetarians to highlight the ancientness of their practice. Today as in Antiquity, the arguments vary while sometimes seeming to echo each other. But to approach ancient vegetarianism requires taking some distance from our contemporary definition if we want to fully grasp the mechanism of thinking of the ancients and understand the reasons for such a practice.

The study of ancient vegetarianism: Difficult beginnings

Faced with carnivorous who remind that human is made to eat meat and cannot live without it, vegetarians most often answer that history since Antiquity

\footnotetext{
8 Think of the works of ethologists Konrad Lorenz or Frans de Waal, among others.

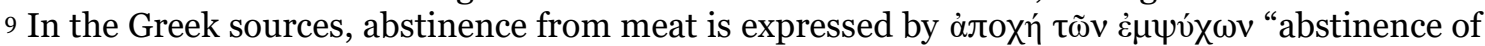
animate beings" (see the Greek title of Porphyry, De abstinentia). Also Plato (Leges VII, 782d)

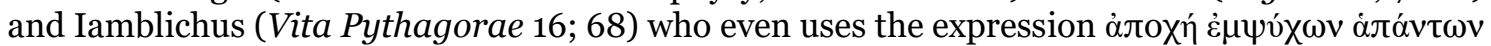

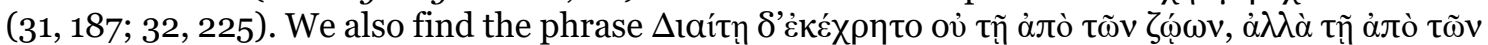

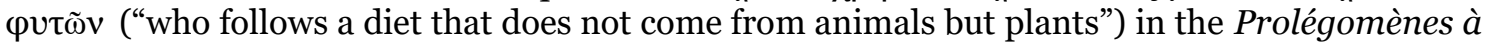
la Philosophie de Platon (2.28-29).
} 
proves that its abstinence is possible and has been advocated very early. The figures of Pythagoras, Socrates, Plato and Plutarch are then put forward as examples. This search for a historical guarantee based on the authority figures of Antiquity is not new. Already in 1887 , Gustav Teichmüller, a vegetarian follower, presented Plato as a supporter of this diet, a claim that Johannes Haussleiter, the first historian to be interested in ancient vegetarianism, laments (Haussleiter, 1935, p. 184-185). After more than ten years of research, he published Der Vegetarismus in der Antike in 1935, a book that remains an essential comprehensive survey for those interested in this question. The author brings together all the Greek and Latin sources that broach vegetarianism between the $6^{\text {th }}$ century B.C. and the $5^{\text {th }}$ century A.C. He classifies them by philosophical groups: pythagoreans, cynics, platonists, peripatetics, stoics, epicureans and neoplatonists/neopythagoreans. The arguments developed in these different sources in favour of vegetarianism are studied and offer an overview. This work, which is less concerned with the history of food than with the history of ideas, is original for the epoch and we would expect historical studies to continue in this direction. However, only Guy Soury published a short paper on this subject in 1946, which is impossible to find today. The publication in Berlin, in 1935, of J. Haussleiter's book at a time when international tensions were strong in Europe, followed by war and the shortages of the post-war period, can explain the marginalization of this theme.

It is in a context of economic development, with the beginnings of the consumer society, that vegetarianism resurfaces tentatively, the turning point being in the 1970 s when the history of food is considered as a social fact and not only economic. Thus, Dario Sabbatucci in his book Saggio sul Misticismo Greco published in 1965 shows in a chapter about orphic vegetarianism that the rejection of meat food is not a simple food issue, but that it is an act whose consequence is civic because it means renouncing the world (Sabbatucci, 1982, p. 73). As for the orphics, who have their own cosmogony, they reject the religious practices of the polis, namely the blood sacrifice and, consequently, the consumption of meat that follows. This analysis taken up by Marcel Detienne in 1970 in his paper "La cuisine de Pythagore" is largely developed in the works that will follow, especially in the collective book La Cuisine du Sacrifice en Pays Grec published with Jean-Pierre Vernant in 1979. Inspired by anthropology, 
particularly the works of Claude Lévi-Strauss which among other things deal with food practices, the authors - two great names of what will later be named "l'École de Paris" - wonder about the relationships established between humans and gods during the sacrifice and show the inextricable link between civic and religious life. Jean-Pierre Vernant and Marcel Detienne describe a bloody sacrifice of alimentary type ( $\theta v \sigma i ́$ ), also called "political sacrifice", which takes place in two stages: the killing of the animal and the consumption of the flesh during a banquet that gathers the civic community while excluding those who are not part of it (metics, slaves, women). More than a religious act, the sacrifice becomes a unifier of the civic life and the civico-religious norm. Then logically, the refusal of a citizen to participate in this ritual and therefore to abstain from meat is analyzed as a wish to stand on the margin of the city. M. Detienne supports his analysis through the example of the orphics and pythagoreans who see in the blood sacrifice a murder. Thus, there is the question of what separates murder from sacrifice. According to Karl Meuli (1946, p. 273, 276), sacrifice is above all "a comedy of innocence" (Unschuldkömodie), that is, a staging that erases all guilt against the vital need of humans to kill and to eat an animal to live. From this idea, J.-P. Vernant (1981, p. 5) explains that violence is ignored at each stage of the sacrificial ritual.

While the knife ( $\mu \alpha \dot{\alpha} \chi \alpha \rho \alpha)$ that will be used to slaughter the domestic animal is hidden in a basket (кavoṽv), the beast is led peacefully to the altar to be slaughtered on the only condition that its sprinkling with lustral water makes it shudder, a sign of its consent. By concealing the violence, the sacrifice is distinct from the murder and the participants can consume the animal's flesh with impunity. This interpretation of the ritual is based on the idea that exists among the Greeks a sense of guilt for killing an animal close to humans in order to consume it. Therefore, this implies that the ancients would not treat the domesticated animal solely as a consumer product. Perhaps this approach has been influenced by works in ethology and in animal ethics which are developing at the same time. Indeed, we notice that it is at that moment, when the issues of suffering and animal welfare appear (think again of P. Singer's book published in 1975), that studies on animals in Antiquity emerge.

The most notable, by its innovative approach, is that of Urs Dierauer published in 1977, Tier und Mensch im Denken der Antike. In his introduction, 
he explains that the choice of such a subject has been carried by the rise of ethology and the growing contemporary interest in the animal question, that is, what distinguishes humans from animals (Dierauer, 1977, p. XV). Indeed, to think that an animal may have welfare or that it may suffer is to consider that it is a sensitive being experiencing not only sensations, but also emotions. This then poses the question of how to behave towards it.

U. Dierauer, observing that this question already exists in Antiquity, proposes to study the human-animal relationship chronologically by using mainly philosophical sources. Using the animal question as a tool for an anthropological and ethical analysis, U. Dierauer focuses on how animals are described compared to humans and the behaviour that the latter adopt towards them. Thus, he shows very clearly that already in the ancient texts the psychological capacities that humans recognize in animals determine their relation, and consequently the ethical discourse on animals. However, the author deliberately leaves aside the animal issue in religion, a subject of its own and largely developed a year later (1978) by Liliane Bodson in 'IEPA Z $2 A$ : Contribution à l'Étude de la Place de l'Animal dans la Religion Grecque Ancienne. As interesting as it is, U. Dierauer's study remains isolated for a long time. Only Richard Sorabji's book Animal Minds and Human Morals. The Origins of the Western Debate, published 16 years later (1993), deals with animal thought and morality in Antiquity while offering a parallel with modern ethical approaches. ${ }^{10}$

Ancient vegetarianism as well does not arouse much publications. Daniel A. Dombrowski in The Philosophy of Vegetarianism, published in 1984, attempts, starting from Antiquity, to broach actual vegetarianism from a philosophical point of view, seeing in the ancient treatises the defense of an ethic. It disregards the variety of arguments in ancient sources and especially shows a partisan reasoning rather than a historical approach. ${ }^{11}$ In 1987, Damianos Tsekourakis presents a paper about Plutarch's arguments on the abstinence of

${ }^{10}$ Later, Newmyer (2006) uses the modern arguments about animal ethic and presents the similitaries with Plutarch's works. Thus, he opens a direct dialogue with R. Sorabji about animal ethic.

11 Although 30 years later D.A. Dombrowski (2014, p. 554) warns against the pitfall of anachronism, he reiterates his position that ancient vegetarianism, as the contemporary one, is focused on animal ethic. 
meat, but these would have deserved a more thorough study. ${ }^{12}$ The same observation can be made for Catherine Osborne who offers in 1995 a very general paper on ancient vegetarianism, relying almost exclusively on Porphyry's treatise De abstinentia.

The result is therefore a real lack of interest from historians that can be explained by two obstacles. The first could be described as "scientific". Ancient vegetarianism appears as a practice restricted to the orphics and pythagoreans, whose testimonies have been repeatedly discussed and classified among philosophical thoughts. Their historical significance has therefore been neglected. It is true that the ancient sources that deal with the abstinence from meat are mainly - indeed exclusively - philosophical, but to approach them as a historian allows for the use of vegetarianism as an analysis tool for social history. The second obstacle is "social". Until the 1970s, vegetarianism was not widespread and its followers were still seen as eccentrics. Meat consumption is not as debated as it is today and remains synonymous of strength (Fiddes, 1991). Noble food prized because it characterizes a varied diet, meat is assimilated to the comfort of life and to success because it is expensive. Its consumption is more encouraged than criticized. Admittedly, physicians like P. Carton or later J. Trémolières encourage abstinence, but meat is not yet decried. It was from the 1970 s with antispeciesist currents that meat began to be perceived negatively.

\section{A historiographic renewal of studies on ancient vegetarianism}

Researches on food, animal and sacrifice open new perspectives, as history adopts a more multidisciplinary approach. While the social history of food has emerged in the studies of Antiquity since the end of 1970s, it is not until it spreads to other historical periods and the modernists and medievalists gain interest in identity practices, in the 1980s-1990s, that food becomes a real field of historical studies for the understanding of societies. The context of "eating together", from that moment on, is no longer accessory, but used as a real object of history to define identities in order to establish a social and cultural history (Flandrin \& Montanari, 1996). In this perspective, Pauline Schmitt Pantel publishes her doctoral thesis in 1992, La Cité au Banquet. Histoire des Repas

\footnotetext{
${ }^{12}$ The similar problem appears in Montserrat Jufresa's paper (1996).
} 
Publics dans les Cités Grecques. The aim of this work is not to establish an "encyclopédie des banquets grecs" (Schmitt Pantel, 1992, p. 1), but to understand what it means to eat during a common meal in the Hellenic world and bring out its value. Food becomes commensality and the unifier of an entity.

Whereas the concept of "social space" in sociology, which appears in the 1980 s, creates a system linking the social, the biological and the ecological, it is only in the 1990s that the sociology of food, for a long time considered futile, gains importance (Poulain, 2012). Already in the years 1979-1980, studies on taste were developed in human sciences, at a time when intensive agriculture, the industrialization of processing, distribution channels and mutations in food practices appeared to be a danger for taste and for good nutrition. With the sociology of food, eaters are at the centre of the analysis and their "plural" practices are highlighted (Corbeau, 1997, p. 69-70; Poulain, 2003, p. 185). Subsequently, researches on food focus more and more on details of alimentary practices (a type of food, cooking, production) using many disciplines and giving birth to the food studies. The creation, in 2001, of the Institut Européen d'Histoire et des Cultures de l'Alimentation (IEHCA) in Tours (France), inaugurated by the publication in 2002 of Histoire et Identités Alimentaires en Europe which was directed by Martin Bruegel and Bruno Laurioux, is a good example. ${ }^{13}$

At the same time, historical studies on animals are multiplying. It is not the place to mention all of them, but it should be noted that this growing interest has opened a genuine field of research in the early 2010s: the animal studies. Multidisciplinary studies are developing and historical researches make of animals a real object of history (Baratay, 2012). For Antiquity, the subject is exploited in its most varied aspects, going from the question of farming (Chandezon, 2003) to the human-animal relationship (Cassin \& Labarrière, 1997; Calder, 2011; Ekroth, 2014; Fögen \& Thomas, 2017). Animals are also taken into account as actors and tools for the study of sacrifice (Wright Knust \& Várhelyi, 2011; Hitch \& Rutherford, 2017). Already from the 1990s, iconographic and archaezoological studies enrich researches on Greek sacrifice, which until now

\footnotetext{
${ }^{13}$ For a summary about food research in the first decade of the $21^{\text {st }}$ century, see the paper by Becker (2012). On the link between anthropology and food studies, see the historiographic summary of Hitch (2015).
} 
had almost exclusively been approached through literary sources. In 1995, with Hiera Kala. Images of Animal Sacrifice in Archaic and Classical Greece, Folkert. T. Van Straten offers a significant iconographic analysis. However, this work has its limits, since it is restricted to a short period (end of the $6^{\text {th }}$ to the end of the $5^{\text {th }}$ century BC) and to a small geographical area (mainly Athens). Therefore, we must rely more on archeozoology for the renewal of the sacrificial issue. By studying the bone remains of animals, this recent field of archaeology allows for the possibility of establishing a typology of sacrificed animals and reopens the question of the context of the animal's killing. Whereas the studies on civic sacrifice $(\theta v \sigma i ́ \alpha)$ had relegated other rituals to the background, the contribution of archeozoology highlights the importance of other sacrifices (mantic sacrifice, holocaust) and the variety of species sacrificed, while confirming the dominance of pigs, sheeps and oxen (Ekroth, 2012; Ekroth \& Wallensten, 2013).

The works carried out in the 1970 s by J.-P. Vernant and M. Detienne showed that sacrifice was not only distinguished from murder by the ritualization of killing, but was also the unifying act of civic life. Although it has allowed for the renewal of the question at the time, this theory, despite or because of its success, is today debated, on three points in particular: the notion of sacrificial victim, the animal's serenity during the sacrificial procession and the consent to its killing. J.-P. Vernant and M. Detienne placed the violence and murder at the centre of the sacrifice: "il y a dans le cérémonial sacrificiel une volonté d'effacer la violence, comme s'il fallait d'avance se disculper de l'accusation du meurtre" (Detienne, 1979, p. 18; Vernant, 1981, p. 6). For J.-P. Vernant, the animal is a sacrificial

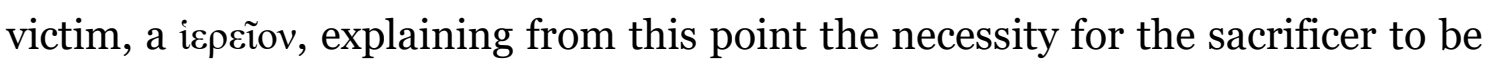
cleared from this act, but also to pass over in silence the killing so that it is not associated with violence and murder. And yet, as Pierre Brulé and Rachel Touzé

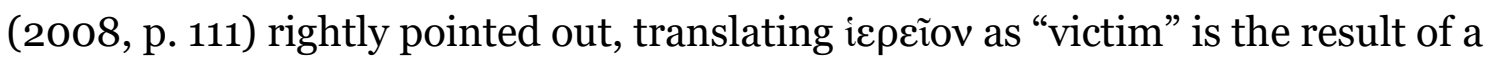
subjective shifting of the analysis of sacrifice.

The animal is destitute of its "sacred" value, which is the most accurate translation of the word, to be presented as a victim, implying an unfair and criminal practice for which it will be necessary to absolve oneself by taking away the responsibility for this act, by resorting to a "comedy of innocence". Similarly, the procession must be serene and the animal must go forward freely. This description is based on many iconographical sources that represent an impassive 
procession where the animal moves peacefully towards the altar, as on the Pitsa panel (Van Straten, 1995, fig. 56). However, basing one's theory on these representations is to neglect the ones showing an animal being dragged with ropes or with its legs held tight, as in the twenty or so representations visible on steles or altars in Asia Minor dated between the 2nd century B.C. and the 3rd century A.C. and analysed by Véronique Mehl (2007, p. 315-316). ${ }^{14}$ To these iconographical sources, can be added the archaeological evidence: many stone blocks equipped with a metal ring used to tie up the animals before their sacrifice have been excavated in the sacrificial area of the sanctuary of Apollo and Artemis at Claros (De la Genière \& Jolivet, 2003, p. 191-192). In addition, there also are

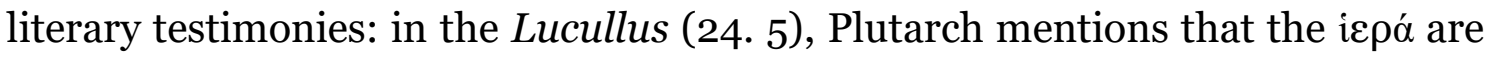

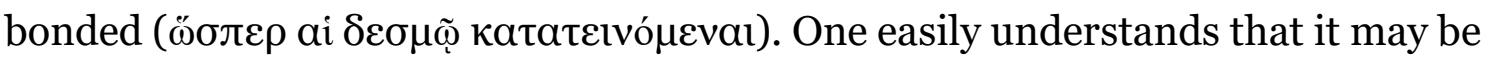
difficult to lead some animals such as an ox "peacefully" to the altar without having to rope it up. Finally, the sprinkling of the animal as a sign of consent in order to erase the guilt generated by the killing is now disputed. Walter Burkert (2005, p. 21), and after him, M. Detienne (1979, p. 18) based their analysis on two sources: a passage from Quaestiones convivales by Plutarch (VIII, 8, 729f) and one from the treatise De abstinentia by Porphyry (II, 9, 3). As a matter of fact, nothing shows in these two sources the existence of any sense of guilt and, as Stella Georgoudi (2005, p. 145) demonstrates, it is rather a matter of making sure that the sacrifice is compliant and permitted by the divinity. Besides, Fred. S. Naiden (2007, p. 71-72) sees in the search for a nod from the animal a sign of vitality, corresponding to a form of ठокциабía.

Recent researches aim at qualifying the approach to sacrifice established by what came to be called the "École de Paris" and refer more and more to sacrifices (Hermary et al., 2004). On the other hand, meat consumption or its renouncement did not arouse much more research. Undoubtedly, the idea that ancient vegetarianism is a marginal practice is well anchored (Freyburger, 2016). Furthermore, the subject seemed, to many historians, impossible to study because of the small number of sources whose historical value appeared insignificant. With the current rise of vegetarianism, we observe that we are dealing with eaters whose choices of abstention from meat are diverse, and it

\footnotetext{
${ }^{14}$ See also Van Straten (1995, fig. 121).
} 
would be more accurate to speak of "vegetarianisms". The animal issue is recurrent but does not constitute the only argument. In the same way, the historian comes to questioning whether ancient vegetarianism was solely practised among the pythagorean and orphic groups and if it was interpreted as a rejection of the blood sacrifice and a will to remain on the margin of the city. Thus, philologists and historians recently came back on a subject long neglected by the sciences of Antiquity.

Thus, Pedro Ribeiro Martins offers an extremely interesting study of ancient vegetarianism in his doctoral thesis Der Vegetarismus in der Antike Streitgespräch. Porphyrios' Auseinandersetzung mit der Schrift “Gegen die Vegetarier", published in 2018. Through a philological analysis of the treatise De abstinentia by Porphyry, he shows that the question of the abstinence from meat has opposed its supporters and its opponents since the $5^{\text {th }}$ century B.C. For this, P.R. Martins bases his work on fragments extracted from a treatise against the vegetarians whose arguments go back to Heraclides Ponticus ( $4^{\text {th }}$ century B.C.), which proves the existence of a real debate on the consumption meat or its abstinence in Antiquity. In fact, the question of vegetarianism goes on during Antiquity, the arguments used being variable, just as the defence of the practice. In this way, vegetarianism becomes object of history and allows to examine the social context.

The soon to be published doctoral thesis Le Végétarisme dans l'Antiquité Grecque by Alexandra Kovacs deals with the question of civic norm and marginality. In a historical approach, the aim is to go back on the trend of making the vegetarian someone excluded from civic life. The analysis of literary sources allows to bring out the arguments brought forward to defend the abstinence from meat and to observe that they evolve according to the social context. The "École de Paris" considers that vegetarian practices are influenced by orphism or pythagoreanism. And yet, the testimonies about these groups are most often dated from the Roman imperial period and far too obscure or contradictory to accurately determine if their abstinence from meat is related to a condemnation of the blood sacrifice. Only Empedocles' poems are a direct testimony, but their fragmentary state make their interpretation abstruse. However, the belief in metempsychosis constitutes a common point, in other words, the fear of the transmigration of a human soul into the body of an animal justifies the abstinence 
from meat, whether among the pythagoreans, the orphics or for Empedocles. From the $5^{\text {th }}$ century on, the Hippocratic treatises recommend a Síalta supporting the philosophers' discourse on the most appropriate way of life for their activity. Frugality, then the eating asceticism, assure temperance and guarantee the access to wisdom which the philosophers are aiming at. From then on, meat appears as a superfluous food which prevents the soul to detach from the body and condemns man to lead an immoderate life, moving away from the true necessities. Thus, meat is not only bad to eat, but also to think.

Furthermore, viewed in its primary state, that is to say as an animal, it arouses many debates around its consumption and the place that should be given to animals in the chain of living things. If the animal is consumed, it is because of its differences with humans. Reason ( $\lambda$ ó ${ }^{\circ} \varsigma$ ) appears as the ability that categorizes living beings and for some, such as the stoics, it makes human superior to animals, the latter only existing to satisfy the needs of the former. Plutarch does not agree with such a stance. Not only he considers that animals have reason, but, because they are useful to humans, these must take care of them. Meat consumption, which implies a killing beforehand, is described as a cruel act in which bursts the intemperance of humans who have let themselves go to an

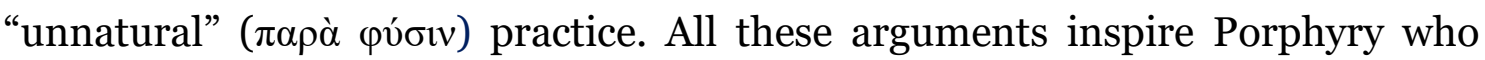
writes, at the middle of the $3^{\text {rd }}$ century A.C., the treatise De abstinentia, the most complete work on this question that has been preserved. Wishing to prove that meat food is harmful to the true philosopher, in other words to the contemplative, Porphyry devotes himself to explaining at length that piety cannot rely on the blood sacrifice. He suggests to resort to bloodless sacrifices: vegetables for those following the natural law and aiming at wisdom; intellective for those who have reached wisdom (the contemplative) by following the divine law. Porphyry's treatise thus demonstrates that when sacrifice is used in the arguments to condemn meat food, it is not questioned as a ritual, but only for one of its categories that is the blood sacrifice.

Besides, the issue of the sacrifice that is most appropriate to piety is at the heart of a debate with Iamblichus who does not condemn the blood sacrifice. Inspired by this philosopher, the Emperor Julian reconciles his imperial function with his philosophico-religious beliefs in which the blood sacrifice is used to affirm paganism facing the development of Christianism. A few decades later, 
when Christianism becomes a state religion, blood sacrifice, while forbidden, is still practiced from time to time in the private sphere by individuals who affirm their attachment to tradition, like Proclus for instance.

We observe that the arguments vary throughout Antiquity, but they also echo each other. A thorough study of the sources reveals that the discourse on the abstinence from meat should not systematically be read as a rejection of blood sacrifice, the latter being only lately summoned in Porphyry's treatise. Recent studies on food in Ancient Greece and the contribution of archaeozoology tend to show that blood sacrifice is not the only occasion to eat meat and is not the only form of sacrifice that was practiced. Consequently, it is not unifying, nor the only way to follow the civico-religious norm and does not imply a strict rule of attendance. Strongly inspired by the research made by the sociology of food, this doctoral thesis shows that the abstinence from meat affirms itself as an identity marker which clearly shows the normative plurality of this practice, adjustable according to the actors involved and/or excluded. Thus, like every food practice, the norms are not excluding, and one person can conform to them according to the social context in which they are shaped. Therefore, vegetarianism does not hamper the citizen's duties and does not lead to marginality within the city. In this study, vegetarianism is thus a research item in history to study the food, religious and social practices, but also allowing to use philosophical texts as historical sources as a means to contribute not only to the history of ideas but also to social history.

\section{Conclusion}

The study of ancient vegetarianism depends on the subjects of research in history. The low interest it aroused among historians for many years can be explained, partly, by a social representation valuing meat. With the rise of animal ethic and multidisciplinary approaches, new historical research items develop both social and cultural history. The rise, these last few years, of the vegetarian phenomenon and the current debates regarding the consumption of meat bring the historian to gain interest in this question. More than a simple study subject of a social practice more or less marginalized, vegetarianism fits into a social context and thus becomes an historical research item. This opens the way for 
different researches which do not only involve food or ethical questions. Conversely, it is preferable, for a solid and scientific approach, to take it out of these two areas and to broach a wider field of study including the civic, religious and cultural questions, allowing to investigate from a new perspective the norms established by societies.

Article received on 18.02.2019, accepted on 28.02.2019.

\section{BIBLIOGRAPHY}

\section{Primary Sources}

Iamblichus. Vita Pythagorae. Michael Von Albrech et al. (eds) Darmstadt: Wissenschaftliche Buchgesellschaft, 2002.

Plato, Leges. Traduit par Auguste Diès. Paris: Les Belles Lettres, 1956.

Plutarch, Quaestiones Convivales. Traduit par Françoise Frazier et Jean Sirinelli. Paris: Les Belles Lettres, 1996.

Belles Lettres, 1972.

. Lucullus. Traduit par Robert Flacelière et Émile Chambry. Paris: Les

Porphyry, De abstinentia. Traduit par Jean Bouffartigue et al. Paris: Les Belles Lettres, 1977-1995.

Prolégomène à la Philosophie de Platon. Traduit par Jean Trouillard. Paris: Les Belles Lettres, 1990.

Secondary Sources

Abrams, H. Leon. Vegetarianism: Another view. In: Kiple, Kenneth F., et al. (eds) The Cambridge World History of Food. Cambridge: Cambridge University Press, 2000, p. 1564-1573.

Baratay, Éric. Le Point de Vue Animal: Une Autre Version de l'Histoire. Paris: Seuil, 2012.

Becker, Karine. Introduction. Un bilan thématique et méthodologique de la recherche actuelle sur l'histoire de l'alimentation. Food \& History, vol. 10, $\mathrm{n}^{\circ} 2$, 2012, p. 9-25.

Bloch Marc. Apologie Pour l'Histoire ou Métier d'Historien. Paris: Armand Colin, 2013.

Bodson, Liliane. 'IEPA ZSA: Contribution à l'Étude de la Place de l'Animal dans la Religion Grecque Ancienne. Bruxelles: Académie Royale de Belgique, 1978.

Bruegel, Martin ; Laurioux, Bruno (orgs) Histoire et Identités Alimentaires en Europe. Paris: Hachette, 2002. 
Brulé, Pierre ; Touzé, Rachel. Le hiereion: phusis et psuchè d'un medium. In: Mehl, Véronique; Brulé, Pierre (orgs) Le Sacrifice Antique. Vestiges, Procédures Stratégies. Rennes: Presses Universitaires de Rennes, 2008, p. 111-138.

Burgat, Florence ; Dantzer, Robert. Une nouvelle préoccupation: Le bien-être animal. In: Paillat, Monique (org.) Le Mangeur et l'Animal. Mutations de l'Élevage et de la Consommation. Paris: Autrement, 1997, p. 69-86.

Burkert, Walter. Homo Necans: Rites Sacrificiels et Mythes de la Grèce Ancienne. Première édition 1972. Paris: Les Belles Lettres, 2005.

Calder, Louise. Cruelty and Sentimentality: Greek Attitudes to Animals, 60o300 BC, Oxford: Archaeopress, 2011.

Cassin, Barbara ; Labarrière, Jean-Louid (eds) L'Animal dans l'Antiquité. Paris: Vrin, 1997.

Chandezon, Christophe. L'Élevage en Grèce (Fin Ve-Fin I Ir s. a.C.). L'Apport des Sources Épigraphiques. Bordeaux: Ausonius, 2003.

Corbeau, Jean-Pierre. Socialité, sociabilité...sauce toujours! In: Duvignaud, Jean; Khaznadar, Chérif (orgs) Cultures, Nourriture, Internationale de l'Imaginaire, Paris: Babel, 1997, p. 69-81.

De la Genière, Juliette; Jolivet, Vincent. Cahiers de Claros II. L'Aire des Sacrifices. Paris: Éditions Recherche sur les Civilisations, 2003.

Detienne, Marcel. La cuisine de Pythagore. Archives de Sociologie des Religions, vol. 29, $\mathrm{n}^{\circ}$ 1, 1970, p. 141-162.

Pratiques culinaires et esprit du sacrifice. In: Detienne, Marcel; Vernant, Jean-Pierre (orgs) La Cuisine du Sacrifice en Pays Grec. Paris: Gallimard, 1979, p. 7-35.

Detienne, Marcel; Vernant, Jean-Pierre. (orgs) La Cuisine du Sacrifice en Pays Grec. Paris: Gallimard, 1979.

Dierauer, Urs. Tier und Mensch im Denken der Antike. Amsterdam: Verlag B. R. Grüner B. V, 1977.

Dombrowski, Daniel. A. The Philosophy of Vegetarianism. Amherst: University of Massachusetts Press, 1984.

Philosophical vegetarianism and animal entitlements, In: Campbell, Gordon Lyndsay. The Oxford Handbook of Animals in Classical Thought and Life. Oxford: Oxford University Press, 2014, p. 535-555.

Ekroth, Gunnel. The Sacrificial Rituals of Greek Hero-Cults in the Archaic to the Early Hellenistic Periods. Kernos, suppl. 12, 2002.

. Animal sacrifice in Antiquity. In: Campbell, Gordon Lyndsay (ed.) The Oxford Handbook of Animals in Classical Thought and Life. Oxford: Oxford University Press, 2014, p. 324-354.

Ekroth, Gunnel; Wallensten, Jenny. Bones, Behaviour and Belief. The Zooarchaeological Evidence as a Source for Ritual Practice in Ancient Greece and Beyond. Stockholm: Svenska Institutet I Athen, 2013.

Fiddes, Nick. Meat. A Natural Symbol. London-New York: Routledge, 1991. 
Fischler, Claude. L'Homnivore. Le Goût, la Cuisine et le Corps. Paris: Odile Jacob poches, 2001.

Flandrin, Jean-Louis; Montanari, Massimo (orgs) Histoire de l'Alimentation. Paris: Fayard, 1996.

Fögen, Thorsten; Thomas, Edmund (eds) Interactions Between Animals and Humans in Graeco-Roman Antiquity. Berlin-Boston: De Gruyter, 2017.

Freyburger, Gérard. Pratique végétarienne et marginalité à Rome. In Amiri, Bassir (org.) Religion Sous Contrôle. Pratiques et Expériences Religieuses de la Marge? Besançon: Presses Universitaires de Franche-Comté, 2016, p. 41-47.

Georgoudi, Stella. L' "occultation de la violence" dans le sacrifice grec: Données anciennes, discours modernes. In: Georgoudi, Stella, et al. (orgs) La Cuisine et l'Autel. Les Sacrifices en Question dans les Sociétés de la Méditerranée Ancienne. Turnhout: Brepols, 2005, p. 115-147.

Georgoudi, Stella, et al. (orgs) La Cuisine et l'Autel. Les Sacrifices en Question dans les Sociétés de la Méditerranée Ancienne. Turnhout: Brepols, 2005.

Haussleiter, Johannes. Der Vegetarismus in der Antike. Berlin: Verlag von Alfred Töpelmann, 1935.

Hermary, Antoine, et al. Les sacrifices dans le monde grec. In: Balty, JeanCharles, et al. (orgs) ThesCRA, vol. 1, Los Angeles: Getty Publications, 2004, p. 59-134.

Hitch, Sarah. Anthropology and food studies. In: Wilkins, John; Nadeau, Robin (eds) A Companion to Food in the Ancient World. Oxford: Wiley Blackwell, 2015, p. 116-122.

Hitch, Sarah; Ritherford, Ian. Animal Sacrifice in the Ancient Greek World. Cambridge: Cambridge University Press, 2017.

Hubert, Annie. Les omnivores deviendront-ils herbivores? In: Poulain, JeanPierre (org.) L'Homme, le Mangeur, l'Animal. Qui Nourrit l'Autre? Paris: Cahiers de l'OCHA, 2007, p. 236-243.

Jeangène Vilmer, Jean-Baptiste. Les principaux courants en éthique animale. In: Engélibert, Jean-Paul, et al. (orgs) La Question Animale. Entre Science, Littérature et Philosophie. Rennes: Presses Universitaires de Rennes, 2011, p. 7992.

Jufresa, Montserrat. La abstinencia de carne y el origen de la civilizacion en Plutarco. In: Fernández-Delcado, José Antonio; Pordomingo Pardo, Francisca (eds) Estudios Sobre Plutarco. Aspectos Formales. Salamanca: Éd. Clásicas, 1996, p. 219-226.

Larue, Renan. Le Végétarisme et Ses Ennemis. Vingt-cinq Siècles de Débats. Paris: Presses Universitaires de France, 2015.

Lepiller, Olivier. La bouffe industrielle à la casserole. Les effets de l'alimentation industrielle par la nutrition et les diététiques alternatives (1965-1985). In: Depecker, Thomas, et al. (orgs) La Juste Mesure. Une Sociologie Historique des Normes Alimentaires. Tours: Presses Universitaires de Rennes-Presses Universitaires François-Rabelais, 2013, p. 115-144.

Lestel, Dominique. Apologie du Carnivore, Paris: Fayard, 2011. 
Loraux, Nicole. Éloge de l'anachronisme en histoire. Le Genre Humain, vol. 27, 1993, p. 23-39.

Kovacs, Alexandra. Le Végétarisme dans l'Antiquité Grecque. (forthcoming).

Martins, Pedro Ribeiro. Der Vegetarismus in der Antike im Streitgespräch. Porphyrios' Auseinandersetzung mit der Schrift “Gegen die Vegetarier”. BerlinBoston: De Gruyter, 2018.

Mehl, Véronique. La corde et le couteau: Une relecture de la mise à mort sacrificielle sur les stèles votives d'Asie Mineure. In: Brun, Patrice (ed.) Scripta Anatolica. Hommages à Pierre Debord. Bordeaux: Ausonius, 2007, p. 315-329.

Meuli, Karl. Griechische Opferbräuche. In: Gigon, Olof (ed.) Phyllobolia für Peter von der Mühll zum 6o. Geburtstag am 1 August 1945. Basel: B. Schwabe, 1946, p. $185-288$.

Naiden, Fred. S. The fallacy of the willing victim. The Journal of Hellenic Studies, vol. 127, 2007, p. 61-73.

Newmyer, Stephen T. Animals, Rights and Reason in Plutarch and Modern Ethics. New York-London: Routledge, 2006.

Osborne, Catherine. Ancient vegetarianism. In: Wilkins, John, et al. (eds) Food in Antiquity. Exeter: University of Exeter Press, 1995, p. 214-224.

Ossipow, Laurence. Le Végétarisme. Vers Un Autre Art de Vivre? Paris: Cerf, 1989.

La Cuisine du Corps et de l'Âme. Approche Ethnologique du Végétarisme, du Crudivorisme et de la Macrobiotique en Suisse. NeuchâtelParis: Éditions de l'Institut d'ethnologie-Éditions de la Maison des sciences de l'Homme, 1997.

Ouédraogo, Arouna P. Le Végétarisme. Esquisse d'Histoire Sociale. Document de Travail. Ivry-sur-Seine: INRA, 1994.

Poulain, Jean.-Pierre. Sociologies de l'Alimentation. Les Mangeurs et l'Espace Social alimentaire. Paris: Presses Universitaires de France, 2003.

Sociologie de l'alimentation. In: Poulain, Jean-Pierre (org.) Dictionnaire des Cultures Alimentaires. Paris: Presses Universitaires de France, 2012, p. 1283-1295.

Sabbatucci, Dario. Essai sur le Mysticisme Grec. Première édition 1965. Paris: Flammarion, 1982

Schmitt Pantel, Pauline. La Cité au Banquet. Histoire des Repas Publics dans les Cités Grecques. Rome: École Française de Rome, 1992

Singer, Peter. La Libération Animale. Première édition 1975. Paris: Payot, 2012.

Sorabji, Richard. Animal Minds and Human Morals. The Origins of the Western Debate. Ithaca: Cornell University Press, 1993.

Soury, Guy. Tabous alimentaires et végétarisme. Humanités, 23, 1946, p. 211-213.

Spencer, Colin. The Heretic's Feast. A History of Vegetarianism. Hanover/London: University Press of New England, 1995. 
Tsekourakis, Damianos. Pythagoreanism or Platonism and ancient medecine? The reasons for vegetarianism in Plutarch's Moralia. ANRW, II, 36.1, Berlin: De Gruyter, 1987, p. 366-393.

Van Straten, Folkert. T. Hiera kala. Images of Animal Sacrifice in Archaic and Classical Greece. Leiden: Brill, 1995.

Vernant, Jean-Pierre. Théorie générale du sacrifice et mise à mort dans la $\theta v o i ́ a$ grecque. In: Reverdin, Olivier (ed.). Le sacrifice dans l'Antiquité. Entretiens sur l'Antiquité Classique, Tome XXVII. Genève: Fondation Hardt, 1981, p. 1-39.

Wright Knust, Jennifer; Varhelyi, Zsuzsanna (eds) Ancient Mediterranean Sacrifice. New York: Oxford University Press, 2011. 